\title{
Tillit fått, mista og fornya
}

\author{
Som lege har eg undra meg over den ufortente tillit eg er vist. Åtferda mi kan bygge opp eller undergrave \\ tillitsposisjonen. Den hjelpetrengjande er sårbar, legen sit med makt. Pasienten opplever meistring eller \\ avmakt, tryggleik eller uvisse, nye sår eller tilheling i konsultasjonen. Eg lever i denne sårbare balansen. \\ Tillit er bærebjelken i den terapeutiske kontakten. Det kan så lett gå gale, bjelken kan brotne.
}

Me er to kollegaer som har arbeidd i lag i 35 år og er blitt som eit gamalt ektepar, for å sitere ein turnuslege hjå oss. Ideologi og arbeidsstil er tilpassa, og på bygda vert me ofte nemnde i same ordelag. Me har lova einannan å seie frå når me får vite at tillit er truga eller tapt. Misnøye er den ultimate kvalitetsparameteren og bør vurderast i ein kollegial samtale. Alltid er det noko å lære. Tillitsbrot er alvorleg for båe partar. Båe lir, demonisering trugar.

I små samfunn kan ikkje den såra unngå å møte den som såra. Byte av fastlege vernar ikkje mot møte på legevakt. Kan legen verte trygg på den såra, familien og venelaget? Kan mista tillit bøtast?

Olav gjorde særs inntrykk på meg. Som ung lege møtte eg han ofte i heimen. Der låg ektefellen til sengs etter mange år med framskridande nevrologisk liding. Heimesjukepleie trongst kvar dag. Soverom og stove romma sjukeseng og rullestol. Olav var trufast til stades som omsorgspersonen over år. Fem born vaks opp. Far måtte vere både far og mor. Olav hadde hatt forskjellig arbeid utanom garden heime. Åra med sjukdom $i$ huset vidareutdanna han til menneskekjennar og omsorgsarbeidar av klasse. Etter at han vart åleine, kom han til å arbeide i kommunal omsorg langt inn i alderdomen.

Hjarterytmen endra seg av og til, han hadde mange vender til legekontoret og sjukehuset. Så vart han svært sjuk. Hjarta ville ikkje samarbeide lenger. Frå sjukehuset kom han på sjukeheimen og var forkomen. Livet gjekk mot enden.

Eg sat ved sjukesenga, sonen sat bak meg. Eg måtte vite kva Olav ville. Han var sliten. Sonen braut inn, han prøvde å forklare fars ynske og innstilling. Eg sat der og reagerte på orda til sonen som utidig støy. Olav måtte få sleppe til! Fleire gonger ville sonen ha meg i tale. Ikkje minnest eg om eg samtala med sonen etterpå. Eg forlét rommet, så var det vaktrom, sjukepleiar, analyse og instruksar. Få dagar etter var Olav død, epoken som far og bestefar var over.

Det går ei heil tid, men så ein dag fortel legekollegaen min at ein av pasientane har sagt at familien til Olav er svært vonbrotne

\section{«Kan mista tillit bøtast?»}

over meg. Dei kjenner seg trakka på. Det søkk i meg, kva skjedde som enda så gale?

Det finst berre ein veg. Eg må snakke med familien, å late som ingenting vil forverre skaden.

Kjenslene prøver å nekte meg å ringe opp sonen, men det må til:

«Det har skjedd noko som var feil, som har såra dykk og som eg treng høyra.» Han dreg på det, i tonefallet ligg skepsis.

På ny: «Eg treng å lære av det som hende. Kan eg få møte dykk?» Det vert avtala dag og tid i heimen.

Med uvisse og spenning møter eg på døra. Sonen kjem ut. Han er nølande, tillitsbrotet teiknar seg i andletet, handa helser meg tvetydig. «Takk for at eg fekk kome». Me går inn i stova. Me set oss andsynes einannan ved salongbordet. «Eg har oppført meg feil. Kan du fortelje kva som hende?» seier eg. Så kjem forteljinga, litt nølande fyrst, men etter kvart med meir trykk, ettertenksamt, med pausar. Han fortel om den fjerne og kalde legen og dei såre siste dagane: «Kvifor oversåg du meg ved sjukesenga? Kvifor var du så avvisande?» Olav og han hadde båe kjent uviljen min, den manglande respekten. Vonbrotet la ei tyngsle over dei siste levedagane. Eg oppførte meg uvenleg og uforsonande, ville ikkje høyre på han. Han opp- levde isnande kulde. Olav var sliten og hadde bede sonen forklare for seg. Eg hadde korkje synt innsikt eller forståing. «Kvifor?» spør sonen.

Magen vrengjer seg. Kvifor hadde eg oppført meg slik? Det var blitt feil! Eg hadde tedd meg uvitug, klart å bruke ei alvorleg og viktig stund til å såre den dødssjuke og sonen hans. Det var arroganse, uvilje og heilagbrot.

«Du har så altfor rett. Eg var uvitug og ukjærleg som tedde meg slik. Olav er død, han kan ikkje tilgi meg, kan du?»

Mea culpa. Skamma kokar i øyremuslingane. Eg har ingenting å orsake meg med. Frå å tenkje at eg er meistrande og kunnig ser eg brått meg sjølv som feilande og fåvis.

Ved kaffibordet går samtalen etter kvart inn på andre banar. Etter måltidet takkar eg for eg fekk kome. I døra tek me einannan ope, trygt og avklåra i hendene. For ei lette.

Det går nokre månader. På vegen opp kyrkjegolvet mot nattverdsbrød og vin står eg brått framom sonen. Overtrampet og erkjenninga kjem over meg att.

«Eg treng nåden meir enn nokon gong», glepp det or meg.

«Det gjer eg og», kjem svaret.

Dei pårørande til pasienten har samtykt til publisering.

\section{Aslak Bråtveit}

aslsigu@online.no

Aslak Bråtveit (f. 1951) er spesialist i allmennmedisin og fastlege ved Finnøy legekontor, Finnøy.

Motteke 4.11. 2015, første revisjon sendt inn 12.1. 2016, godkjent 25.1. 2016. Redaktør: Ketil Slagstad. 